\title{
The realities people live by: A critical reflection on the value of Wolfgang Iser's concept of repertoire for reading the story of Susanna in the Septuagint
}

\begin{tabular}{|c|c|}
\hline \multicolumn{2}{|c|}{$\begin{array}{l}\text { Author: } \\
\text { S. Philip Nolte }\end{array}$} \\
\hline \multicolumn{2}{|c|}{$\begin{array}{l}\text { Affiliation: } \\
{ }^{1} \text { School of Ancient } \\
\text { Languages, North-West } \\
\text { University, Potchefstroom } \\
\text { Campus, South Africa }\end{array}$} \\
\hline \multicolumn{2}{|c|}{$\begin{array}{l}\text { Note: } \\
\text { Dr S. Philip Nolte was a } \\
\text { postdoctoral fellow of Prof. } \\
\text { Pierre J. Jordaan at the } \\
\text { School of Ancient Languages, } \\
\text { North-West University, } \\
\text { Potchefstroom Campus, } \\
\text { South Africa. This article } \\
\text { forms part of his research } \\
\text { program. }\end{array}$} \\
\hline \multicolumn{2}{|c|}{$\begin{array}{l}\text { Correspondence to: } \\
\text { Philip Nolte }\end{array}$} \\
\hline \multicolumn{2}{|c|}{$\begin{array}{l}\text { Email: } \\
\text { philip.nolte@iburst.co.za }\end{array}$} \\
\hline \multicolumn{2}{|c|}{$\begin{array}{l}\text { Postal address: } \\
\text { PO Box } 908164 \text {, Montana } \\
\text { 0151, South Africa }\end{array}$} \\
\hline \multicolumn{2}{|c|}{$\begin{array}{l}\text { Received: } 21 \text { Aug. } 2012 \\
\text { Accepted: } 20 \text { Jan. } 2013 \\
\text { Published: } 11 \text { Apr. } 2013\end{array}$} \\
\hline \multicolumn{2}{|c|}{$\begin{array}{l}\text { How to cite this article: } \\
\text { Nolte, S.P., 2013, 'The } \\
\text { realities people live by: A } \\
\text { critical reflection on the } \\
\text { value of Wolfgang Iser's } \\
\text { concept of repertoire } \\
\text { for reading the story of } \\
\text { Susanna in the Septuagint', } \\
\text { HTS Teologiese Studies/ } \\
\text { Theological Studies 69(1), } \\
\text { Art. \#1320, } 7 \text { pages. http:// } \\
\text { dx.doi.org/10.4102/hts. } \\
\text { v69i1.1320 }\end{array}$} \\
\hline \multicolumn{2}{|c|}{$\begin{array}{l}\text { Copyright: } \\
\text { (C) 2013. The Authors. } \\
\text { Licensee: AOSIS } \\
\text { OpenJournals. This work } \\
\text { is licensed under the } \\
\text { Creative Commons } \\
\text { Attribution License. }\end{array}$} \\
\hline \multicolumn{2}{|l|}{ Read online: } \\
\hline 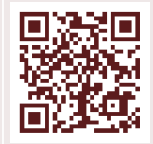 & $\begin{array}{l}\text { Scan this QR } \\
\text { code with your } \\
\text { smart phone or } \\
\text { mobile device } \\
\text { to read online. }\end{array}$ \\
\hline
\end{tabular}

The article investigates the value of Wolfgang Iser's concept of repertoire for reading the apocryphal story of Susanna. The viewpoint is that fictional literature such as the Susanna narrative and reality are not opposites of each other, but that fictional texts tell us something about reality. The investigation will also include Peter L. Berger's theory on how religion contributes to construct social reality. The study will show that religious texts construct the reality(ies) in which people interact and try to make sense of everyday existence. Two stories contemporary to the writer of the article are employed to show that in a certain sense male perceptions about women have not changed much over two millennia. The critical engagement with the narrative will also ask how Susanna's story can be interpreted in a responsible and ethical way that is conducive for the constructive development and transformation of individuals and communities.

\section{Introduction}

\section{Rihanna's song}

A video of the song, Man Down (see Rihanna 2011), performed by the R\&B star, Rihanna, was posted on YouTube in June 2011. The video portrays the killing of a man by a young woman after he had raped her. It begins with the killing scene whilst the remainder describes the circumstances leading to the killing, in which the rape scene is portrayed. The song also describes the woman's remorse over what she had done. A whole array of voices present scathing critique against the graphic portrayal of the killing scene in the video were launched against Rihanna. In the United States of America (USA) the group, Mothers Against Violence, asks that the video be withdrawn from YouTube, because it 'influences vulnerable individuals' (quoted in Lee 2011). Melissa Henson of Parents Television Council says: 'Instead of telling victims they should seek help, Rihanna released a music video that gives retaliation in the form of premeditated murder' (quoted in Lee 2011). On the other hand, highly acclaimed South African journalist Marianne Thamm (2011:3) is of the opinion that the reaction is a misrepresentation of what the song is about, and gives positive comment on what she sees as being the meaning of the video. She asks why men are allowed to sing about rape, but not women.

Whether one agrees with Rihanna's critics, or with Thamm, the fact of the matter is that the video tackles a very important topic in society, namely male sexual violence against women. The context of the video is that of a sexy, young Black woman who challenges the accepted culture that she has to deal with and it compels one to reflect on the complicated issues concerning sexual stereotypes. Neither the song nor the video is meant to promote revenge or the killing of a perpetrator, but rather to portray the tragic consequences of sexual violence. On a deeper level it also portrays cultural stereotypes that deform women into sexual objects.

\section{Cheryl Araujo's rape}

Rihanna's song is not the first time that an artist tackles this contentious issue. In 1988 the actress Jodie Foster played the lead role in the film The Accused (see Kaplan 1988). The film is based (the information on the film in the following paragraphs comes nearly verbatim from The Accused) on the real-life gang rape of Cheryl Araujo that occurred at Big Dan's Bar in New Bedford, Massachusetts, on 06 March, 1983, and was one of the first Hollywood films to deal with rape in a direct manner.

The story is about a working-class woman, Sarah Tobias (played by Foster), labeled as promiscuous. One night in a bar, she is gang raped by several drunk bar patrons, whilst drunken onlookers cheer them on. A district attorney, Kathryn Murphy (played by actor Kelly McGillis), is assigned to the rape case, and wants to drop the case. After a heated argument, she is admonished by 
her superior to enter a plea bargain with the rapists requiring some jail time. Sarah is enraged by the deal because she considers it a light punishment and because she did not get an opportunity to tell her story in court.

When Sarah is hospitalised after ramming her car into a pickup truck, whose driver (one of the witnesses in the case who had encouraged the rapists) crudely propositions her, Kathryn decides to prosecute the men who cheered the rape for criminal solicitation. Sarah's friend Sally, a waitress at the bar where the rape took place, picks three men out of a line-up, and they get three different attorneys for the ensuing trial. Sarah testifies that she was raped, whilst college student Kenneth Joyce, whose friend was one of the rapists, testifies to watching the rape prior to making a 911 call. The three men were found guilty and sentenced to jail time for reckless endangerment.

\section{Cultures and narratives}

One may ask whether such an elaborate introduction of rape and sexual violence to this article is valid. After all, Susanna's story ends well, and it is just a story. For that matter, Rihanna's video is also only a story of fiction. The issue at stake, however, is not whether a narrative is 'real' or 'fictional', but rather about the cultures that created those narratives. In both the Rihanna-video and the Jodie Foster movie (The Accused) we are confronted with cultures that condone men to view women as sexual objects. I am not talking about judicial systems which form part of those cultures and are meant to protect women and let justice prevail. I am talking about a cultural environment that is hazardous to women, instead of being conducive for the protection and the development of their gender and identity, and more importantly, to view them as human beings and not as objects.

Although there is a time difference of more than two thousand years between the song by Rihanna and The Accused on the one hand, and 'Susanna'1 on the other hand, it seems that many things still have not changed after more than two millennia. We still find ourselves confronted with male-dominated cultures as the one from which 'Susanna' originated. In spite of positive developments women are still seen and used by many men merely as sexual objects. For the purposes of my argument I identify three differences between the video and movie on the one hand, and 'Susanna' on the other hand:

- Firstly, we find a difference between the protagonists in the stories. In Rihanna's song the young lady who has been raped acts as her own protagonist. In this case one may ask whether her action is a comment on the cultural system in which she lives (which includes the judicial system), or is it 'only' an emotional reaction ending in killing the perpetrator, or is it both? In The Accused a male college student and a female district attorney act as protagonists. Cheryl Araujo also had access to a judicial system that ultimately favoured her case. In 'Susanna' (a

1.References to the biblical text are written as 'Susanna' whereas references to the character in the story are written without quotation marks. male) God and Daniel (a male person) are the protagonists and Susanna survives.

- The second difference can be seen in the roles of the victimised women and the outcomes of the stories. In both the Man Down video (see Rihanna 2011) and The Accused the women get a chance to tell their own stories and are thereby empowered to become agents of change in their own lives. Susanna, however, never gets a chance to tell her story and she is ultimately put back in her place in the reigning patriarchal culture of her time.

- The third difference concerns people's access to judicial systems. In the Jamaican society which is the background to the Man Down video, women have access to a judicial system which is meant to bring sex offenders to justice. In the American society women also have access to a wellestablished justice system as portrayed in The Accused. The society from which 'Susanna' originated was a quite different one as will become clear in the ensuing paragraphs.

In spite of the differences at least two common denominators can be traced in all three stories:

- The first commonality is the perception that women are available as sexual objects to be used by men as they wish, and if women do not want to go along they are brutally forced into submission.

- The second common thread is that none of the stories really succeed to change these degrading perceptions about women. In the South African society, girls as young as nine months are raped and lesbian women are gangraped to 'cure' them from their homosexual orientation. In South Africa we have an annual initiative called 'The initiative against violence against women and children' during the first sixteen days of December. This says a lot about our society at large.

The aim of my article is to reflect on the role of cultural and/or social environments in the creation of literature and ask whether it is relevant today to read ancient texts such as 'Susanna'. I shall argue that religious texts are utilised to construct the realities and societies within which people interact and try to make sense of everyday existence. Societies are not predetermined worlds in which people exist passively. Human beings participate in constructing their realities and societies in creative or destructive ways. Literary texts are part of this interaction between people and their different worlds. Texts are not just reflections of reality but may challenge, deconstruct, inform and maintain reality. The article will show if and how the 'Susanna' narrative reflects, challenges and maintains certain cultural values. The critical engagement with the narrative will also ask how Susanna's story can be interpreted in a responsible and ethical way - a way that is conducive for the constructive development and transformation of individuals and communities, especially in the South African society where sexual violence is part of the daily struggle of thousands of women.

To facilitate the discussion I make use of Wolfgang Iser's concept of repertoire as he describes it in his book The act of 
reading: A theory of aesthetic response (1978). ${ }^{2}$ The debate will play out within the boundaries of two topics Iser uses in his discussion, namely 'the referential system of the repertoire' as well as his deliberation on 'general systems theory'. These two topics will be employed to reflect on the way in which we can interact in a meaningful way with 'Susanna'. Iser's (1978:53-58) objective is to move away from so-called 'ontological arguments' about literature which focus on what texts 'mean', to 'functional arguments' which focus on what texts ' $\mathrm{do}^{\prime}$. The underlying theory for this movement is that texts are meant to communicate something to someone. When arguing from this point of view it becomes obvious that one has to ask: communicate what to whom and for what reason? The moment one asks these kinds of questions, one has to consider the context of the text as well as the context of the reader. All communication takes place within social realities. These realities influence the content of and the way in which texts are constructed as well as people's interpretations of those texts.

\section{The referential system of the repertoire}

Texts are not islands in a vast sea of life without any connection to the realities surrounding them. Iser (1978) formulates this insight as follows:

The repertoire consists of all the familiar territory within the text. This may be in the form of references to earlier works, or to social and historical norms, or to the whole culture from which the text has emerged - in brief, to what the Prague structuralists have called the 'extratextual' reality. (p. 69)

Textual references to reality are not mere replicas of that reality, but these references undergo some kind of transformation. The reason for this is that texts are the products of authors' interpretations of the realities in which they live. A text such as 'Susanna' generates certain viewpoints by transforming the identity of the elements it takes over from reality, thus creating a dialogical situation in which these elements could be scrutinised. The situation created in 'Susanna' is that of a fictional story which invites readers to consider its values and viewpoints without openly alienating the readers from the beginning by stating that Jewish judges are corrupt people who abuse their power. The text uses Israel's arch enemy, Babylon, as the scapegoat for corrupting the judges and therefore the Jewish society in Babylon (v. 5). Ancient readers of the story would readily agree with the view that 'wickedness came from Babylon' (v. 5). The story also legitimises this kind of evil by stating that 'the Lord' had predicted it long ago (v. 5). In other words, it could be expected that judges who are corrupted by Babylon would be evil. By using this kind of rhetorical tactic the story defuses any kind of criticism towards the reigning values in the culture of the time. ${ }^{3}$

2.An important part of Iser's (1978:54-68) discussion on this topic includes 'speechact theory' and 'situation building'. Both of these themes are of great value for the reading of literary texts, but are not my focus in the article.

3.In the South African society of 1948-1990 the same kind of reasoning was used by legitimising apartheid as God's will, using certain Bible texts as cases in point.
From my point of view as a reader in a postmodern South African society, I ask the question why the story ends with upholding the values it seems to challenge. The story is about the wife of an influential husband whose household has been shamed. A male youth, Daniel, is put in the spotlight as the hero who could, with God's inspiration, unmask the evil underlying the judges' actions. Susanna's family stays silent throughout the whole ordeal. Susanna never finds herself in a position in which she could transform into a full character with insight into God's values and therefore as a woman with her own voice. Her only insight is formulated as follows:

Then Susanna sighed, and said, I am straitened on every side: for if I do this thing, it is death unto me: and if I do not, I cannot escape your hands. It is better for me to fall into your hands, and not do it, than to sin in the sight of the Lord. With that Susanna cried with a loud voice: and the two elders cried out against her. (vv. 22-24)

Susanna's only 'insight' is into the societal and religious laws that would render her guilty, no matter what she does. The main character of the story is thus neatly stripped of (1) the opportunity to take responsibility for her own life, and (2) to open the door for the 'main' character, Daniel, who voices her plight and unmasks the situation for what it is, namely a society with a blind spot for evil in its midst. Thus, the focus shifts from a just woman, who is ostracised by her community, to a wise male youth through whom God's wisdom and insight flows. In my opinion, the issue at stake is not only an unawareness of evil exercised by two judges, but also an underlying paradigm that women are subservient to men and that a woman's role in that society is to uphold her husband's honour at all costs, even if it means that she has to die. Of course, the community was not able to see this because they were socialised into very specific roles and functions for males and females.

Jennifer Glancy (1993) formulates her interpretation of Susanna's position as follows:

I question Susanna's assertion - and thus the ideological stance of the text - that acting to preserve her life would be a sin against the LORD, since an implicit premise of her statement is that any rape victim is by definition guilty. The terms in which she frames her alternatives indicate that she perceives herself to have no real choice; the elders' power over her is presented as an inescapable fact of the situation. (p. 112)

Glancy's ideological critical reading strengthens my point of view that it is in fact the ideological system of patriarchal dominance which Susanna was part of that rendered her guilty. The reactions of all the parties involved - the slaves, Susanna's family, Joachim, the community - illustrate that Susanna was already found guilty of adultery, inter alia because the legal condition that a transgression has to be corroborated by two male witnesses, was complied with. Susanna's version of what happened is never considered. Men ruled and decided her fate. Even God did not dare to interfere with the system by giving Susanna a voice of her own. Only male voices are heard. The only female voice is that of Susanna crying out to the Lord, although there is no indication in the story that she expects God to rescue her. She expects to be killed and chooses to die by staying obedient to 
God, which really means obedience to the patriarchal values in her society, rather than giving in to the evil of the elders.

Susan Sered and Samuel Cooper (1996:43-55) read the narrative from a cultural-anthropological framework which highlights important aspects related to the obvious, but largely hidden, power structures in the story. Sered and Cooper (1996:43-44) identify a constellation of binary oppositions in the narrative that show that Susanna has no access to structural or socially recognised power in her society. She is part of the so-called socially weak, but at the same time as someone with moral power. Authority and social power situated in men, and everything else in society had to be subservient to male dominance.

Because Susanna was part of a social system that did not give her access to structural or socially recognised power, I utilise Iser's (1978:70-70) description of 'general systems theory' to reflect on how power structures are created and maintained in social systems. I shall also make use of Peter L. Berger's views on how societies are constructed and the role religion plays in this process to further reflect on this issue. Berger ([1967] 1990:3-51) develops a valuable theory on the role of religion in the shaping of reality and societies, and therefore his observations are of importance for my study.

\section{General systems theory and 'Susanna'}

People's views of the realities they live in differ because our views of reality are always interpreted views of reality. Therefore, when we say that literary texts relate to reality, we refer to 'models or concepts of reality, in which contingencies and complexities are reduced to a meaningful structure. We call these structures world-pictures or "systems"' (Iser 1978:70). Iser (1978:71) utilises Niklas Luhmann's views on systems and systems theory, as well as an earlier work by Luhmann and Jürgen Habermas to describe the relevance of general systems theory ${ }^{4}$ for literary theory. It is important to be cognisant of the fact that cultural or social values form part of and are determined by the larger social systems that surround them, and that the latter form part of a larger, pervasive historical environment. Therefore it makes sense to take the socio-cultural systems in which literary texts originate into account when reading those texts. A very brief overview of Luhmann's theory, as it pertains to this study, will follow in the next few paragraphs. ${ }^{5}$

\section{Social systems and their environments}

Systems come into being when 'a border can be drawn between a set of communications and the context of the

4.General systems theory or systems theory is an interdisciplinary field which studies systems as a whole. The pioneers in developing this theory were Ludwig von Bertalanffy and William Rosh Ashby amongst others. They built their theories on findings in physics, biology and engineering. Today systems theory is used in a wide variety of disciplines such as sociolog. a wide variety of disciplines such as sociology, law, philosophy, organisational and management theory, literary theory and psychology (family systems theory). Niklas aspects that are conducive for what I want to achieve with this article.

5.See Luhmann (1973); and Habermas and Luhmann (1971), for an in depth study into Luhmann's theory. The information used in this article to reflect on the relevance of Luhmann's theory for my area of focus can be found in Iser (1978:71-79). communication, or the systems environment' (Wikibooks 2011:6). Systems or societies operate in environments which are larger and much more complex than the societal systems themselves. The normal tendency of all systems is to create meaning and make sense by following a process of selection. This selection takes place through communication which can be described as 'coordinated selectivity' (Wikibooks 2011:6). For Luhmann, communication is a selection performed by a system, and not an action performed by an individual person. In this sense Luhmann differs from the everyday view of communication, namely as a sender sending a message through the medium of language (oral or textual or body language) to a sender within the parameters of a given context, which frequently focuses on interaction between individuals. N.A. Anderson (2003) describes this selection process that Luhmann calls 'communication' as a fusion of three separate selections, namely: the selection of information, the selection of a form, and the selection of understanding. The selection of information entails selecting between different possibilities. The form of the message is a decision on how the message will be communicated, which has to do with genre for example, prose or poetry. The selection of understanding has to do with what should be understood by a message. This does not refer to reception of a message by readers or hearers, but involves the linkage of a message to subsequent communications. Social systems create meaning through this selection process and use it to construct and sustain themselves.

A social system creates boundaries between itself and its environment by choosing from complex exterior possibilities a set of possibilities which gives meaning to the lives of the people who are part of that system. Communication within a system is focused on selecting only the amount and the kind of information that is advantageous for the ongoing existence of that system. The choice to render certain kinds of information truer than others, or even as 'the truth', is normally exercised by those who control power relations in societies. Normally, only the information that is deemed beneficial to maintain the internal structures of the system is allowed and communicated. Information that challenges the system is viewed with suspicion and opposed, and usually not allowed to be communicated. Individuals who are seen as a threat are stigmatised as deviants, or as 'heretics' in the case of religious systems.

According to general systems theory, each system has a structure of regulators which creates a definitive order throughout the system. These regulators have several interrelated functions which can be summarised as follows (Iser 1978:71):

- They provide a framework for social action.

- They serve as a protection against insecurities arising out of the contingent world.

- They supply an operational set of norms that claim universal validity and so offer a reliable basis for our expectations.

- They must also be flexible enough to adapt to changes in their respective environments. 
These functions can only be fulfilled when systems reduce the complex realities they have to operate in, and they do this by selecting some possibilities as dominant and natural, and others as excluded and unnatural for that particular social system. No system can incorporate the larger world of which it forms part in its totality, therefore every system relates to its complex world by means of selective references. This selection forms part of what I call a system's ideology, and is meant to bring about the stabilisation of certain expectations. These expectations take on normative and continual validity and are enabled in this way to regulate the processing of experiences in our everyday world. The ideological system underlying the Rihanna music video and the Jodie Foster movie (The Accused), communicates the view that girls who dress sexy and act in a certain way in public can expect to be sexually abused and raped. This is what happens to 'those kinds of girls'. In Susanna's case, although she did not dress provocatively, the ideology of the day communicated that women were male property and therefore available to men as they pleased. In this way, the different social systems degrade female persons to objects of male desire. None of the women in Rihanna's video, The Accused or 'Susanna' were asked for their participation. They were simply seen as being available to male dominance.

Iser (1978:71) further argues that literary texts take prevalent thought systems or social systems as their contexts, but they interfere with those structures by setting up parallel frames within which meaningful patterns can be formed. I am not convinced that this is always the case. Sometimes literary texts strengthen the prevalent social systems that they take as their contexts. I am of the opinion that this is what happens in 'Susanna', although it may seem to challenge the reigning thought system. In this respect, I agree with Glancy (1993:115) that the gender mechanisms in the narrative render the character of Susanna almost entirely as object. 'Susanna' does not succeed to challenge the prevalent social system of male dominance and female subservience, and therefore no 'parallel frame within which meaningful patterns are to form' (Iser 1978:71) is constructed. The only meaningful parallel frame would be one within which Susanna could transform from an object of male dominance to a person with her own voice. This could have been done by the author through giving Susanna the opportunity to tell her side of the story, as well as through depicting her family, her slaves and the community as people who are interested in listening to her. However, because of the prevalent system this option was not available to the author. Therefore, the only way in which Susanna could be vindicated was by a male person 'ordained' by God. Berger's views on how societal values are religiously legitimised are conducive for developing my arguments in a more nuanced way. Therefore I shall now proceed to a short description of the role of religion in constructing reality.

\section{The relationship between religion and world- building}

Individuals form part of societies and societies are human products. Iagreewith Berger, that reality is socially constructed and that religion forms part of that process of world-building ([1967] 1990:3-51). There can be no society or social reality without human action and creativity, because of the dialectic interaction between people and society. Dialectic interaction means that people create society, but also that people are the product(s) of society. It is within society, through social processes, that individual people become persons and find their accorded roles and places within the worlds they live. According to Berger ([1967] 1990:4), the dialectic process consists of three moments, namely, (1) externalisation, which entails people's physical and mental activity in the world; (2) objectivation, which means that people experience the very society they create subjectively as an objective reality external to themselves; and (3) internalisation, which has to do with processes through which people appropriate structures from their surrounding world as values and rules necessary for meaningful living.

What interests me is how societal structures and values relate to people and their functioning in the world. Society is experienced by people as an objective presence 'out there' over which they have no control, and which prescribes their place and role in society. Society exercises coercive power over individuals in the sense that it controls and directs thinking and behaviour, for example through political and legal institutions. What is of interest for this article is that:

the fundamental coerciveness of society lies not in its machineries of social control, but in its power to constitute and to impose itself as reality. The paradigmatic case of this is language. (Berger [1967] 1990:12)

People do not have control over the societies they are born into and within which they live. Societies assign roles and identities to people which individuals internalise unconsciously as reality. By unconscious I mean that individuals normally do not question the roles and identities they are socialised into. These roles and identities are further established and maintained in society by the dominating myths, stories, texts and everyday speech, in other words, by language.

Another important aspect of Berger's theory ([1967] 1990: 29-51) which pertains to this study is the process of legitimation. The purpose of legitimation is to justify a specific social order. It answers questions about the 'why' of social institutions. Religious legitimation happens when empirical reality is related to an ultimate reality, in other words it is given 'cosmic status' (Berger [1967] 1990:36). This kind of legitimation is a very powerful one, because it links people's lives, their roles in society and their behaviour, to an ultimate reality that cannot be questioned. People are told that 'this is how God intends it to be.' Human behaviour depends largely on the recognition of others and insofar as they have identified themselves with the roles they are supposed to play in society. People grow up with the idea that they are only accepted insofar as they adhere to the rules pertaining to their supposed roles, and when these roles and rules are embedded within a religious system it becomes very difficult to deviate from socially acceptable behaviour. Deviation is 
viewed as invoking chaos within a divinely sanctioned order and can ultimately lead to marginalisation, social ostracism, and in certain religious groups to excommunication.

The society from which 'Susanna' originated, presented itself as a male dominated reality in which women were viewed as part of male property. Women were socialised into certain roles and functions and were not allowed to cross the boundaries that were set up as reality by their society. The texts, myths and everyday speech of the day focused on maintaining that society. Individual people become that which they are addressed as by others. Constructing society is a collective enterprise in which 'the individual appropriates the world in conversation with others, and, furthermore, that both identity and world remain real to himself as long as he can continue the conversation' (Berger [1967] 1990:17). However, the dilemma is what happens when such a conversation is not possible, or rather only possible within the framework of perpetuating a hierarchical society where some individuals and groups are viewed from the beginning as of lesser value than others and are not able to make a valuable contribution to the conversation? The 'thin thread of conversation' (Berger [1967] 1990:17) that helps to shape people's identity was not available to Susanna or any other woman of her time. The conversation that shaped people's identities in ancient Judaism was a patriarchal one with a static view on personhood.

As stated above, individuals appropriate their objective worlds into their subjective consciousness through a process of internalisation. In other words, people perceive themselves and others according to the cues they receive from their societies and they act accordingly. The results of such a process of internalisation can be seen in 'Susanna' in terms of the roles assigned to the different characters. Bruce Malina's (2001) reflection on ancient Mediterranean societies helps us to understand the underlying values that shaped those societies, of which honour and shame were two fundamental values (see also Neyrey 2004; Malina \& Rohrbaugh 1992; Malina \& Neyrey 1991:25-65; Bechtel 1991:47-76). In the Mediterranean, especially in the past, kinship has been the focal point of society. This means that the family is the primary institution and belongingness is the organising principle of life. Having the proper relationships with the right people is very important. The central group in such a society is one's kinship group:

A person's identity depends on belonging to and being accepted by the family. Such belonging and acceptance, however, depend on a person's adhering to the traditional rules of order by which Mediterranean families are organized and maintained. And those traditional rules of order are rooted in the complementary codes surrounding the basic values of honour and shame. (Malina 2001:29)

The culturally acknowledged values of honour and shame function within a wider framework of authority, gender status and respect. Authority has to be understood as a symbolic reality and has to be distinguished from physical force. Authority relates to people who control the behaviour of others. Gender status has to do with the way in which biological gender differentiation is symbolised in societies. Certain roles and functions are 'female', and others are 'male' and are recognised in a social group. By respect is meant the attitude one must have and the behaviour one is expected to follow relative to those who control one's existence. In the Jewish society of Susanna's time the cultural framework of honour and shame was alive and well and it determined the way in which the people involved reacted to Susanna's socalled adultery.

Malina (2001:149; see also Malina \& Rohrbaugh 1992:53) describes adultery as conceived in Old Testament times in this way: 'Adultery, of course, symbols grave trespass into the space of a fellow honorable male, a clear negative challenge requiring vengeance as a response.' A married woman in ancient Jewish culture was socially and psychologically embedded in the family as well as the honour of her husband. Her behaviour was supposed to maintain the honour and therefore the social status of her husband as well as that of his family (Osiek 2006:819-843; Malina 2001:46-51; Countryman 1988:158). She had to be careful not to bring shame upon her husband. ${ }^{6}$ A woman was also seen as her husband's property that, in this sense, has to be understood as 'an extension of the self, so that a violation of my property is a violation of my personhood' (Countryman 1988:147). In ancient Judaism, a wife was brought in from another family in order to preserve and sustain that of her husband through the bearing of children and the wise administration of the household. The ideal destiny of a woman was to be some man's wife, which was the best position a woman could aspire to in ancient Israel (Countryman 1988:155). The wife did not, properly speaking, become part of her husband's family but was seen as part of his property, as can be seen in the way Deuteronomy equates the acquisition of house, vineyard and wife (Dt 20:5-7; 24:14 ; 28:30). What provided further legitimacy to this kind of patriarchal culture was the fact that it was mystified as being God's will. This can be seen in Susanna's reaction when the elders threatened to 'expose' her as an adulterer (vv. 21-23).

Within this cultural framework adultery was seen as a crime against sexual property and it came down to bringing shame on a married man by 'stealing' his wife. The husband's honour was connected to the continuity of his family line through legitimate heirs, and adultery, that could include sexual intercourse, endangered this. When another man had intercourse with a married woman, it added up to stealing her husband's right to have legitimate heirs. Like the loss of any other property to someone else, this shamed the husband and his family's status in the community. This meant that Joachim's honour was violated and that he could take the recourse available to him; he could have both Susanna and the perpetrator killed if the intercourse were consensual, or have the perpetrator killed if intercourse was against Susanna's will (Dt 22:23-27). Since the man (men) in question could not be found, only Susanna had to stand trial.

6. Honour was a pivotal value in the ancient Jewish world. See Neyrey (2004); Malina (2001), Malina and Rohrbaugh (1992), Bechtel (1991:47-76), Malina and Neyrey (1991:25-65) for comprehensive treatments of this issue. 
It is clear, according to the values of the Judaic society of the time that Susanna's honour was not important at all. Even Susanna's family was powerless to intervene on her behalf, because the two elders were giving testimony and the 'jury' had decided. The family had to abide by the rules of the day and accept the elders' judgement. The two judges acted in accordance with the regulations of Deuteronomy 19, which stipulate that a matter in court must be established by the testimony of two or three witnesses. Glancy (1993:106) shows that the plausibility of a narrative is to make its ideology seem natural or inevitable which is precisely what happened in 'Susanna'.

\section{Findings}

The investigation showed that Iser's theory on the repertoire of the text is valuable when reading ancient texts such 'Susanna'. I have also shown the relevance of Iser's utilisation of Luhmann's development of general systems theory for the purposes of the investigation. The value of these theories lies inter alia in an awareness of the fact that authors and readers are continuously shaped by the prevailing cultural or societal values of their time.

I further illustrated the significance of Berger's theory of how religion helps to shape social reality, specifically his theory on legitimation, for the interpretation of ancient religious texts. The investigation makes it clear that religious texts can only be read responsibly when the cultural contexts they originated in are taken seriously.

It has been illustrated in what way the patriarchal culture of the time influenced views on maleness and femaleness, namely that women were seen as men's property.

The study showed that cultural and/or social environments play a vital role in the creation of literature and that religious texts are used to legitimise society as being in accordance with a higher power, such as God. It has been shown that religious legitimation makes it very unlikely if not impossible for people to challenge the values of their societies.

I showed that the patriarchal values of the time permeated the whole story. The author of 'Susanna' did not challenge these values, but used a male person, Daniel, to save Susanna who was viewed as not being capable to save her own life. It would not have been the honourable thing to do in ancient Jewish society for a woman to act on her own behalf. I have illustrated this by showing that Susanna was not allowed to tell her own story and passively accept the system of the time. The article showed that although 'Susanna' initially seems to challenge the patriarchal values of the time, it maintains those values in the end. By utilising the Man Down (Rihanna 2011) song of Rihanna and The Accused I have shown that many perceptions about women have not changed from ancient times to our own time.

My focus is to engage critically with religious texts in such a way that they could be read in a responsible and ethical way that is conducive for the constructive development and transformation of individuals and communities. The South African society is perceived as a very religious one where up to $75 \%$ of the population describe themselves not only as being religious, but as Christian. In spite of this, sexual violence is part of the daily struggle of thousands of women and children in South Africa. Religious texts could be used for the transformation of such a violent and gender-biased society only when the underlying ideologies of those texts are deconstructed and read for what they are, namely as ancient documents embedded in ancient cultures whose values differ from our own. By becoming aware of how society and social values are constructed, perhaps we can learn to write other kinds of texts and liberate ourselves and others form harmful perceptions and behaviour.

\section{Acknowledgement Competing interest}

The author declares that he has no financial or personal relationship(s) which may have inappropriately influenced him in writing this article.

\section{References}

Anderson, N.A., 2003, Discursive analytical strategies: Understanding Foucault, Koselleck, Laclau, Luhmann, Policy Press, Bristol.

Bechtel, L.N., 1991, 'Shame as sanction of control in Biblical Israel: Judicial, political, and social shaming', Journal for the Study of the Old Testament 49, 47-76. http:// dx.doi.org/10.1177/030908929101604903

Berger, P.L. [1967] 1990, The sacred canopy: Elements of a sociological theory of religion, Anchor Books, New York.

Countryman, L.W., 1988, Dirt, greed, and sex: Sexual ethics in the New Testament and their implications for today, Fortress Press, Philadelphia. PMid:2849118, PMCid:282869

Glancy, J.A., 1993, 'The accused: Susanna and her readers', Journal for the Study of the Old Testament 58, 103-116. http://dx.doi.org/10.1177/030908929301805808

Habermas, J. \& Luhmann, N., 1971, Theorie der Gesellschaft oder Sozialtechnologie: was leistet die Systemforschung, Suhrkamp Verlag, Frankfurt (Main).

Iser, W., 1978, The act of reading: A theory of aesthetic response, transl. The Johns Hopkins University Press, Routledge \& Kegan Paul Ltd., London. PMCid:1605021

Kaplan, J., 1988, The Accused, motion picture, Paramount Pictures Corporation, Los Angeles, viewed n.d., from http://en.wikipedia.org/wiki/The_Accused_(1988_ film)

Lee, A., 2011, 'Rihanna's Man Down video should be banned, says US pressure groups', in Metro, viewed 12 August 2011, from http://metro.co.uk/2011/06/02/ rihannas-man-down-video-should-be-banned-say-us-pressure-groups-36442/

Luhmann, N., 1973, Zweckbegriff und Systemrationalität. Über die Funktion von Zwecken in sozialen Systemen, Suhrkamp Verlag, Frankfurt (Main). PMid:4587376

Malina, B.J., 2001, The New Testament world: Insights from cultural anthropology, rev. \& expanded edn., Westminster John Knox Press, Louisville. PMCid:34606

Malina, B.J. \& Neyrey, J.H., 1991, 'Honor and shame in Luke-Acts: Pivotal values of the Mediterranean world', in J.H. Neyrey (ed.), The world of Luke-Acts: Models for interpretation, pp. 25-65, Hendrickson, Peabody.

Malina, B.J. \& Rohrbaugh, R., 1992, Social science commentary on the Synoptic Gospels, Fortress, Minneapolis. PMCid:195351

Neyrey, J.H., 2004, Render to God: New Testament understandings of the divine, Fortress, Minneapolis.

Osiek, C., 2006, 'The New Testament teaching on family matters', HTS Teologiese Studies/Theological Studies 62(3), 819-843. http://dx.doi.org/10.4102/hts. v62i3.382

Rihanna, 2011, Man Down, video recording, A. Mandler, (director), Sham of The Juggernauts (Production), Jamaica, in YouTube, viewed 12 August 2011, from https://www.youtube.com/watch?v=sEhy-RXkNo0

Sered, S. \& Cooper, S., 1996, 'Sexuality and social control: Anthropological reflections on the book of Susanna', in E. Spolsky (ed.), The judgment of 'Susanna': Authority and witness, pp. 43-55, Scholars Press, Atlanta. (Society of Biblical Literature: Early Judaism and its literature 11).

Thamm, M., 2011, 'Waarom mag mans daarvan sing maar vrouens nie?', Rapport (Bylaag 2), 12 Junie, bl. 3.

Wikibooks, 2011, Communication Theory/Social systems, 6, viewed 19 August 2011, from http://en.wikibooks.org/wiki/Communication_Theory/Social_Systems 